\title{
Tipologi Arsitektur Tradisional Mamasa, Sulawesi Barat
}

\author{
Mithen \\ Jurusan Teknik Sipil dan perencanaan \\ Fakultas Teknik Universitas Negeri Makassar \\ mithen.lullulangi@gmail.com
}

\begin{abstract}
ABSTRAK
Mamasa merupakan salah satu kabupaten di Provinsi Sulawesi Barat yang mempunyai budaya lokal tersendiri, dan permukimannya masih ada yang mempertahankan iklim tradisional. Hingga saat ini, populasi arsitektur tradisional Mamasa masih terdapat di 7 kecamatan, terdiri atas 30 situs kampung tradisional dengan kondisi yang semakin berkurang. Tujuan penelitian ini adalah untuk mengetahui tipologi rumah tradisional Mamasa sebagai upaya inventarisasi dan dokumentasi arsitektur tradisional Mamasa. Metode penelitian dilakukan secara kualitatif-eksploratif melalui survei dan observasi ke situs-situs populasi arsitektur tradisional yang masih ada di beberapa perkampungan, serta melakukan wawancara kepada orang-orang tua yang masih mengetahui seluk-beluk rumah tradisional. Teknik analisis data dilakukan secara tipologi dengan cara membandingkan hasil wawancara dengan responden serta penelitian sebelumnya. Produk pengumpulan data berupa hasil wawancara serta foto-foto lapangan. Hasil penelitian menunjukkan bahwa ada lima jenis tipologi rumah tradisional Mamasa, terdiri atas: 1) banua longkarrin (rumah sederhana), 2) banua rapa' (rumah yang berwarna alami), 3) banua disussuk (rumah yang diukir khusus), 4) banua bolong (rumah yang berwarna hitam), dan 5) banua sura' (rumah ukir).
\end{abstract}

Kata kunci: tipologi, rumah tradisional, Mamasa

\begin{abstract}
Mamasa is one of a regency in West Sulawesi Province, which has a special local culture and part of the settlements were still maintain their traditional scene. Presently, the number of Mamasa traditional buildings is still exist in 7 districts, consist of 30 traditional village sites, but continue decreasing. This research aimed to find out the tipology of Mamasa traditional houses for inventory and documentation of Mamasa traditional architecture. This research was performed by qualitative-explorative technique through survey and observation at the site. Subsequently, this research carried out interview to the respondents which still have information about Mamasa traditional houses. Analysis was performed by making building typology, by comparing interview result and previous research. Product of data collection are interview transcripts and site images. Findings indicates that there are five tipology of Mamasa traditional houses, which are: 1) banua longkarrin (Simple house); 2) banua rapa'; (natural colour house) 3) banua disussuk (Special carving house) 4) banua bolong; (black house) and 5) banua sura' (Carving house).
\end{abstract}

Keywords : tipology, traditional houses, Mamasa

\section{Pendahuluan}

Arsitektur tradisional adalah salah satu aset nasional yang sangat besar artinya dan perlu dilestarikan, karena arsitektur tradisional mempunyai nilai budaya yang tinggi sehingga dapat memberi wawasan Langkau Betang: Vol. 2, No.1 (ISSN 2355-2484) yang luas kepada para perencana dalam melakukan perancangan dan pembangunan, khususnya yang berkaitan dengan ciri khas arsitektur daerah tertentu (aliran vernakular). 
Arsitektur tradisional dari berbagai suku bangsa di Indonesia pada saat ini, ada yang sudah diteliti dan didokumentasikan, tetapi masih ada yang belum utamanya arsitektur dari berbagai sub etnik yang justru mempunyai karakteristik serta keunikan tertentu yang dapat dijadikan modal dasar dalam pembangunan pariwisata. Begitu pun kondisinya, ada yang masih dipelihara dan dihuni, ada yang hanya berfungsi sebagai objek wisata, bahkan ada yang tidak dipelihara lagi dan terancam punah.

Wilayah Mamasa, adalah suatu wilayah yang secara geografis berada di atas pegunungan dengan luas $2.759,23 \mathrm{~km}^{2}$, dan diresmikan menjadi kabupaten tersendiri berdasarkan UU No.11 tahun 2002 merupakan pemekaran dari kabupaten Polewali Mamasa Provinsi Sulawesi Barat.

Penduduknya merupakan sub etnik Toraja dan Mandar (peralihan dari suku Toraja dan suku Mandar). Wilayah ini kaya akan potensi alam dan budaya yang dapat dijadikan modal dasar pembangunan, utamanya pembangunan pariwisata yang dapat dikembangkan untuk mendukung pendapatan asli daerah (PAD). Salah satu potensi budaya yang ada, adalah arsitektur tradisional Mamasa yang mempunyai ciri khas tersendiri. Secara sepintas lalu, kelihatan seperti arsitektur tradisional Toraja pada umumnya tetapi jika diperhatikan secara seksama, ternyata ia mempunyai karakteristik tersendiri utamanya dari segi proporsi, tata ruang, tata letak, jenis, dan lain-lain.

Begitu pun modal kepariwisataan (Tourism assets) berupa panorama alam, flora dan fauna, budaya, dan minat khusus sangat besar dan dapat dikembangkan, sehingga dapat dibangun menjadi daerah tujuan wisata utama di Sulawesi Barat, yang dapat terpadu dengan tujuan wisata utama Sulawesi Selatan, yaitu Tana Toraja. Perpaduan antara kekayaan alam yang menarik dengan arsitektur tradisional yang unik akan sangat menarik untuk dikembangkan sebagai modal dasar pembangunan pariwisata di daerah ini.

Persoalannya adalah arsitektur tradisional yang ada, populasinya semakin berkurang akibat pengaruh modernisasi yang melanda daerah ini selama bertahuntahun. Minat masyarakat untuk memelihara rumah tradisional mereka semakin Langkau Betang: Vol. 2, No.1 (ISSN 2355-2484) berkurang, mengingat bahwa dari segi fungsional dan pandangan praktis rumah tradisional seperti ini kurang sesuai lagi dengan aktivitas masyarakat modern, di samping biaya pemeliharaan cukup besar.

Keadaan ini berlangsung sejak dekade 1950-an sampai tahun 1980-an. Nanti setelah adanya wisatawan yang merambah ke wilayah ini, dan adanya kesadaran untuk melestarikan budaya mereka baru ada perhatian untuk merenovasi dan memelihara bangunan-bangunan tradisional yang masih sisa, walaupun sudah banyak yang hancur dan lapuk akibat cuaca dan hujan.

Saat ini, populasi arsitektur tradisional Mamasa masih terdapat di 7 kecamatan, terdiri atas 30 situs kampung tradisional dengan kondisi berbeda-beda, ada yang masih dihuni dan ada yang sudah terancam hancur.

Oleh karena belum adanya upayaupaya penelitian, inventarisasi, dan dokumentasi tentang arsitektur tradisional Mamasa sebagai salah satu unsur budaya bangsa yang hampir punah, sehingga penelitian ini dilakukan sebagai salah satu upaya untuk mengisi kekosongan literatur tentang arsitektur tradisional Mamasa. Peneliti tertarik untuk menyumbangkan pikiran dan meneliti masalah ini, khususnya tipologi arsitektur rumah tradisional Mamasa setelah mendapat kepercayaan dan rekomendasi serta fasilitas dari Bappeda Kabupaten Mamasa.

\section{Kajian Literatur \\ 2.1 Arsitektur}

Arsitektur adalah hasil dari proses perancangan dan pembangunan seseorang/sekelompok orang dalam rangka memenuhi kebutuhan ruang untuk melaksanakan kegiatan tertentu. Arsitektur dapat juga berarti seni bangunan, ilmu yang mempelajari tentang bangunan, atau lebih lanjut Mangunwijaya (1992) mengatakan: Istilah arsitektur dalam bahasa Jawa Kuno adalah Wastuwidya (vastu-wastu $=$ bangunan, vidia-widya $=$ ilmu). Pengertian ini lebih luas dan menyeluruh jika dibandingkan dengan kata Yunani Architectonicas (seni bangunan) yang berarti pembangunan utama atau ahli pembangunan.

John Ruskin (Anonim 1998), mengatakan: " architecture mirrors the 
various aspects of our life, social, economic and spiritual ". Dia mengatakan bahwa arsitektur mencerminkan berbagai aspek kehidupan meliputi masyarakat, ekonomi dan spiritual.

Le Corbusier dalam Hellman (1988), mengatakan bahwa: "Architecture is the masterly, correct and magnificient play of masses brought together in light". la mengatakan, arsitektur adalah permainan massa bangunan yang mengagumkan, benar dan berharga dari massa massa, yang dibawa untuk di padukan dalam pencahayaan.

Siegel (1962), mengatakan: "Architecture is an art, science, human beings, material, politic, and money". Arsitektur adalah seni, ilmu pengetahuan, manusia, bahan bangunan, politik, dan uang.

Perkembangan arsitektur sejalan dengan perkembangan peradaban manusia dari periode ke periode berikutnya, dimana manusia membutuhkan ruang sebagai wadah kegiatan hidup dengan aman, nyaman, bermanfaat, dan dapat memberikan kenikmatan dan rasa kebahagiaan.

Berdasarkan beberapa pendapat di atas, dapat disimpulkan bahwa pengertian arsitektur adalah suatu karya dalam merancang dan merencanakan ruang sebagai wadah kehidupan manusia yang bermanfaat dan dapat memberikan rasa kebahagiaan pada periode waktu tertentu.

\subsection{Arsitektur Tradisional}

Kata tradisi adalah hasil transkripsi dari bahasa Inggris tradition, yang dapat diartikan sebagai kebiasaan turun-temurun dari satu generasi ke generasi berikutnya.

Dalam Kamus Umum Bahasa Indonesia, Poerwadarminta (1984), kata Tradisi berarti: "Segala sesuatu seperti adat, kepercayaan, kebiasaan, dan sebagainya yang turun-temurun dari nenek moyang".

Selanjutnya, Mattulada (1992) mengatakan, "Tradisi adalah bahagian dari tabiat kebudayaan". Lebih lanjut dikatakan bahwa: "Adapun yang dimaksud dengan unsur tradisional di sini, adalah aspekaspek kultural yang dikonservasi sehingga dapat bertoleran pada apa yang disebut 'wajah budayah' yang didalamnya terdapat jati diri masyarakat dan kebudayaan itu sendiri.
Dalam kaitannya dengan arsitektur, masalah penting adalah arsitektur bertradisi dan tradisi berarsitektur. Arsitektur bertradisi adalah arsitektur yang dibangun dan dihuni sesuai dengan kaidah-kaidah tradisional. Hampir sama dengan apa yang dinamakan arsitektur tradisional. Sedangkan tradisi berarsitektur lebih mengacu kepada kegiatan sosiobudaya, atau masyarakat menyebutnya sebagai kegiatan dalam membentuk atau membina arsitekturnya; atau bagaimana masyarakat menyatakan dirinya melalui arsitektur.

Ruskin (1992) mengatakan bahwa : "The concept of tradition in architecture was key in preserving at the some time the idea that architecture belongs to past ages." la mengatakan, konsep tradisi dalam arsitektur adalah kunci melestarikan gagasan bahwa arsitektur milik masa lampau.

Jika pengertian arsitektur dihubungkan dengan pengertian tradisi, maka arsitektur tradisional adalah perancangan dan pembangunan yang dilakukan dengan cara yang sama sejak beberapa generasi tanpa perubahan yang berarti, dalam rangka memenuhi kebutuhan ruang untuk melaksanakan kegiatan tertentu.

Dari berbagai suku bangsa yang mendiami berbagai daerah di Indonesia, sejak berabad-abad lamanya telah membentuk karakteristik budaya dan arsitektur masing-masing. Itulah sebabnya sehingga terjadi beraneka ragam bangunan tradisional mulai dari bentuk yang sederhana, hingga bentuk yang sempurna yang berdiri berkelompok maupun yang tunggal, masing-masing mempunyai ciri khas atau kekhususan sesuai dengan pandangan hidup masingmasing suku.

Pertumbuhan dan perkembangan arsitektur tradisional bersamaan dengan perkembangan suatu suku bangsa. Karena itu, arsitektur tradisional merupakan salah satu identitas dari suatu suku atau masyarakat yang mendukungnya, dan melaui arsitektur tradisional tercermin kepribadian masyarakat pendukungnya.

Tradisi berarsitektur di beberapa kawasan di Indonesia ini, juga terbentuk dari suatu proses dimana proses tersebut tidak terjadi dalam keadaan terisolasi, melainkan ada unsur-unsur luar yang bertransfusi ke dalam nilai lokal, menyatu 
dan menyelesaikan tantangan yang dihadapi sehingga memiliki suatu otentisitas.

\subsection{Tipologi Arsitektur}

Barliana (2004) mengatakan, Tipologi adalah kajian tentang tipe. Tipe berasal dari kata Typos (bahasa Yunani), yang bermakna impresi, gambaran (imej), atau figur dari sesuatu Secara umum, tipe sering digunakan untuk menjelaskan bentuk keseluruhan, struktur, atau karakter dari suatu bentuk atau objek tertentu. Lebih lanjut ia menjelaskan, bila ditinjau dari objek bangunan, tipologi terbagi atas tiga hal pokok, yaitu site (tapak) bangunan, form (bentuk) bangunan, dan organisasi bagian-bagian bangunan tersebut.

Berdasarkan pengertian ini, dapat pula dijelaskan bahwa tipologi arsitektur adalah kegiatan yang berhubungan dengan klasifikasi atau pengelompokan karya arsitektural dengan kesamaan ciri-ciri atau kekhususan yang diciptakan oleh kelompok masyarakat yang terikat dengan adat-istiadat atau budaya yang tetap. Kesamaan ciri-ciri tersebut antara lain kesamaan bentuk dasar, sifat dasar, kesamaan fungsi objek, dan kesamaan asal-usul sejarah yang terikat oleh kepermanenan dari karakteristik yang tetap.

Dari pengertian ini, dapat ditarik kesimpulan bahwa tipologi arsitektur tradisional Mamasa adalah klasifikasi atau kelompok arsitektur tradisional yang mempunyai ciri-ciri bentuk, site, dan karakteristik yang sama yang dijumpai di wilayah Mamasa secara keseluruhan.

\section{Metode Penelitian}

Metode penelitian yang digunakan dalam penelitian ini adalah metode survey dan kualitatif. Peneliti mendatangi semua situs perkampungan tradisional yang masih ada, melakukan pemotretan terhadap objek yang diteliti, serta mengadakan wawancara terhadap orang-orang tua yang masih mengetahui seluk-beluk arsitektur tradisional tersebut. Data penelitian berupa foto-foto dan hasil wawancara, dianalisis secara tipologi, diinterpretasi, serta dibandingkan dengan literatur yang sudah ada, dinarasikan secara kualitatif dan disusun dalam bentuk buku laporan penelitian.

\section{Hasil dan Pembahasan}

Berdasarkan hasil wawancara dengan para responden, terungkap bahwa arsitektur tradisional Mamasa, terdiri atas rumah, lumbung padi, dan kuburan. Ketiga jenis bangunan ini mempunyai karakteristik masing-masing. Rumah sebagai tempat hunian dan aktivitas manusia ada yang berfungsi adat dalam artian selain rumah itu berfungsi sebagai hunian, juga ditempati untuk membicarakan, dan melaksanakan adat-istiadat yang harus dipatuhi dalam masyarakat. Lumbung sebagai tempat menyimpan padi, dan kuburan tradisional dari berbagai tipe yang kesemuanya itu memperkaya corak arsitektur tradisional Mamasa.

Khusus arsitektur tradisional rumah, terdiri atas beberapa jenis sesuai dengan strata sosial dan fungsi adat, seperti yang ditulis oleh Mandadung (1999) bahwa: rumah tradisional Mamasa, terdiri atas: (1) Banua Layuk atau rumah pemangku adat yang diukir dan dibuat tinggi, (2) Banua Sura' atau rumah ukir tetapi tidak dibuat tinggi dan dihuni oleh bangsawan tinggi tapi tidak memangku adat, (3) Banua Bolong atau rumah tradisional yang berwarna hitam yang dihuni oleh bangsawan biasa, (4) Banua Rapa' atau rumah biasa, tidak diukir dan tidak berwarna hitam tetapi berwarna alami (natural color) dihuni oleh bangsawan biasa tetapi tidak kaya atau juga dihuni oleh orang kebanyakan, dan (5) Banua Longkarrin atau rumah biasa yang dihuni oleh masyarakat kebanyakan.

Bonggalangi (2013) sebagai seorang responden menjelaskan bahwa rumah tradisional Mamasa terdiri atas: 1) banua lentong patondok; 2) banua longkarrin; 3) banua rapa'; 4) banua bolong; 5) banua disussuk. Lebih lanjut Bonggalangi menjelaskan bahwa banua lentong patondok adalah jenis rumah yang sangat sederhana, biasanya hanya terdiri dari dua lanta' (dua ruangan) yaitu lombon (ruang belakang) dengan ba'ba, (ruang depan) longanya (atap depan yang mejulang tinggi) pendek saja dan tidak pakai penulak (tiang utama di longa). Seperti yang diperlihatkan pada gambar 1 .

Banua longkarrin adalah peningkatan dari banua lentong patondok tapi bagian bawah lentong (tiang) ada kayu yang dipasang membujur yang disebut longkarrin. Jumlah ruang pada rumah ini, 
juga biasanya dua buah yaitu lombon (ruang belakang tempat memasak dan tidur), dan ba'ba (ruang depan tempat menerima tamu). Selain dari pada itu, rumah jenis ini juga sudah dilengkapi longa (atap yang menjulang tinggi di depan rumah) dan penulak (tiang utama yang bundar dan tinggi mendukung longa), walaupun penulaknya kecil. (Gambar 2).

Banua rapa' adalah jenis rumah tradisional yang sudah komplit. Ukurannya juga besar dan tiangnya terdiri dari lentong (tiang) utama dan lentong alla' (Tiang tengah). Penulaknya sudah ada yang di belakang dan di depan dan jika longanya panjang kadang-kadang penulak depannya dua buah. Dari segi tata ruang, sudah komplit yaitu: lombon (ruang belakang), tambing (ruang khusus), ba'ba (ruang tengah), dan tado' (ruang depan). Ornamennya juga sudah lengkap kecuali ukiran. Rumah jenis ini sudah ada yang dipasangi badong (ornamen yang dipasang mencuat di depan atau di belakang, rumah) baik badong belakang maupun badong depan, lebih-lebih jika yang empunya rumah ingin memberi warna hitam ( akan dibolong), seperti yang diperlihatkan pada gambar 3.

Banua bolong (rumah berwarna hitam) adalah rumah yang ditempati para bangsawan dan orang kaya. Jenis rumah ini dari segi proporsi, tata ruang, ornament dan sebagainya sama saja dengan banua rapa' tapi yang membedakan hanyalah warnanya yang sudah dihitami. Sebenarnya, banua bolong ini adalah peningkatan dari banua rapa' yaitu ketika yang empunya rumah sudah merasa mampu dapat saja mambolong (menghitami) rumahnya, yang selanjutnya dapat lagi ditingkatkan menjadi banua sura' (rumah ukir) ketika yang empunya rumah sudah merasa mampu untuk mengukirnya. (Gambar 4).

Banua sussuk (rumah yang diukir dengan pa'sussuk). Adalah jenis rumah yang khusus diperuntukkan kepada para pemangku adat. Pa'sussuk adalah jenis ukiran tua yang sangat sederhana yang berbentuk lurus, baik vertical maupun horizontal. Bentuk ukiran ini bermakna simbolik yaitu yang berbentuk vertical melambangkan hubungan manusia dengan penciptanya dan yang berbentuk horizontal melambangkan hubungan manusia dengan sesamanya. Karena makna simbolik yang begitu mendalam, sehingga jenis rumah ini hanya diperuntukkan bagi para pemangku adat yang mempunyai tugas dalam masyarakat sebagai penghubung antara manusia dengan penciptanya maupun jadi mediasi dalam hubungan antar manusia.

Responden lain. Tandirandan (2013) menjelaskan bahwa klasifikasi rumah tradisional Mamasa dimulai dari yang sangat sederhana, yaitu: 1) barung-barung; 2) banua sulekka; (3) banua ditobanni; (4) banua rapa;; (5) banua sussuk (passura' tomatua); dan (6) banua bolong lalu disura'.

Banua barung-barung adalah rumah yang sangat sederhana, terdiri dari konstruksi bangunan yang sangat sederhana dengan material struktur sederhana pula. Tata ruang hanya terdiri atas satu ruangan, yaitu ruangan untuk makan, tidur dan dapur menyatu. Jenis rumah ini biasanya dihuni oleh orang miskin atau golongan hamba pada masa lampau. Disamping itu, juga sering dibangun di sawah atau di kebun sebagai rumah sawah atau rumah kebun yang ditempati pada saat kerja sawah atau kerja kebun.

Banua sulekka, konstruksinya juga masih sederhana dan merupakan peningkatan sedikit dari barung-barung. Fungsinya pun sama dengan barungbarung. Yang membedakan adalah tata ruang karena banua sulekka sudah terdiri atas dua ruangan (dua lanta').

Banua ditobanni adalah jenis rumah yang dibuat dengan konstruksi khusus, di mana ujung lentong (tiang) bagian bawah dipasangi kayu yang melintang dan membujur yang berfungsi sebagai pondasi. Begitu pun ujung lentong bagian atas, juga ditutup dengan kayu melintang dan membujur, sehingga rangkaian konstruksi tiang merupakan toban (box) segi empat panjang dan di atas box itulah badan rumah dipasang. Rumah jenis ini biasanya sudah dipasangi longa tapi belum memakai penulak. Dan kalau ada yang pakai penulak, biasanya sangat kecil. Dari segi tata ruang, rumah jenis ini biasanya terdiri atas dua ruangan yaitu lombon dengan ba'ba.

Banua rapa' adalah jenis rumah yang sudah memakai konstruksi yang lengkap. Penulaknya ada yang satu buah, dua buah, bahkan ada yang tiga buah. Tata ruang, ada yang hanya tiga ruang (Iombon, ba'ba,

Hal. 5 
dan tado'), tetapi ada juga yang empat ruang (lombon, tambing, ba'ba, dan tado'). Jika jenis rumah ini ada rencana untuk ditingkatkan menjadi banua bolong atau banua sura' (rumah ukir), biasanya sudah dilengkapi dengan badong baik badong belakang maupun badong depan.

Banua sussuk agak menarik, Walaupun bentuk, struktur dan konstruksinya sama dengan banua rapa' atau banua bolong tetapi tidak dipersiapkan untuk ditingkatkan (dibolong baru disura'). la langsung disussuk atau diberi ukiran dengan corak khusus yaitu jenis ukiran vertical dan horizontal. Jenis rumah ini pun biasanya diperuntukkan khusus kepada orang-orang tertentu yang mempunyai jabatan adat dalam suatu komunitas masyarakat. (Gambar 5).

Banua bolong dan banua sura' adalah jenis rumah yang sudah mengalami proses peningkatan dari banua rapa' yang berwarna kayu alamiah (natural color) menjadi berwarna hitam. Bahan untuk menghitami yang sebenarnya adalah bone (sejenis tumbuhan yang biasanya tumbuh di hutan), tetapi sekarang ini, sudah ada orang yang memakai bahan cat.

Setelah yang empunya rumah sudah merasa mampu, merekapun meningkatkan rumahnya menjadi banua sura' (rumah ukir). Dimana ukiran itu sendiri penuh dengan makna simbolik yang merupakan pesan dan ciri khas untuk membedakan fungsi adat atau kebangsawanan seseorang dalam masyarakat. Warna ukiran ada empat macam, yaitu: merah, putih, hitam dan kuning yang diambil dari bahan-bahan alamiah seperti jenis bebatuan, tanah liat, dan daun-daunan. Makna warna ukiran itu sendiri, menurut Rebong (2012) adalah: hitam simbol rambu solo' (acara kedukaan) warna merah simbol keberanian, warna putih simbol rambu tuka' (acara syukuran) dan warna kuning simbol kebangsawanan. (Gambar 6).

Menyangkut tipe rumah, Rebong (2012) juga membagi atas: 1) banua toban; 2) banua kala'popok; 3) banua sondong; 4) banua sura'; 5) banua bolong. Menurutnya, dalam pengklasifikasian ini yang tertinggi adalah banua bolong. la berpendapat bahwa banua sura' tingkatannya lebih rendah daripada banua bolong. Pendapat ini juga didukung oleh Pai'pinan (2013) yang mengatakan bahwa : "Nilai-nilai Langkau Betang: Vol. 2, No.1 (ISSN 2355-2484) rumah adat yang paling tinggi adalah banua bolong sebab banua sura' adalah merupakan perkembangan baru dan asalnya dari banua bolong kemudian disura' (diukir)."

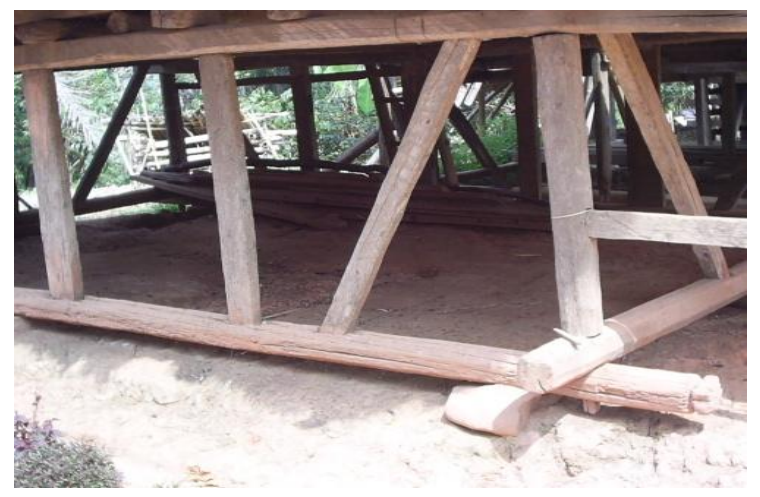

Gambar 1: Memperlihatkan model tiang rumah lentong (tiang) banua toban / Tulekken.

Sumber: Hasil Penelitian, 2013

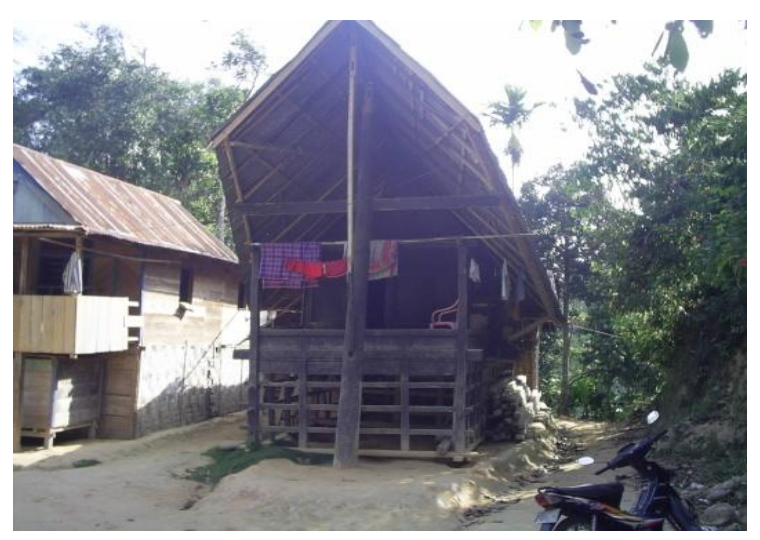

Gambar 2: Tipe banua Longkarrin Sumber: Hasil Penelitian, 2013

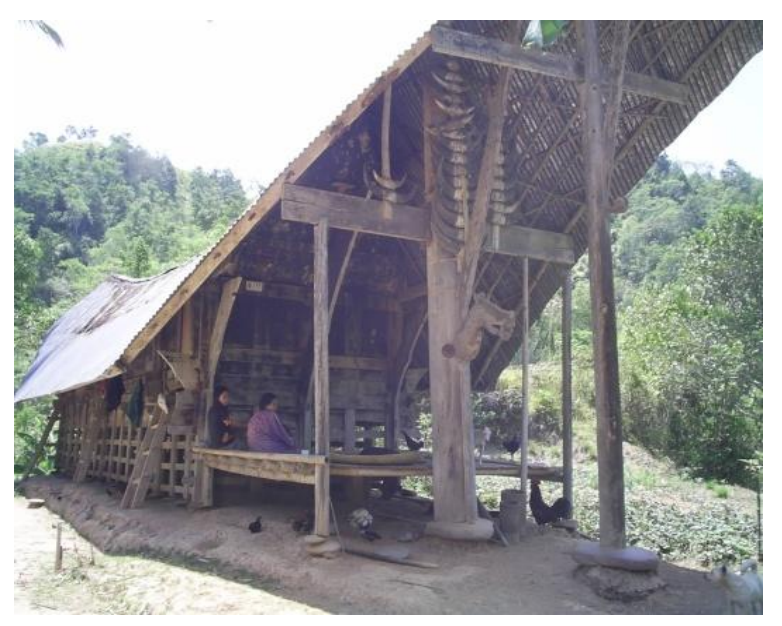

Gambar 3: Tipe banua rapa'

Sumber: Hasil Penelitian, 2013 


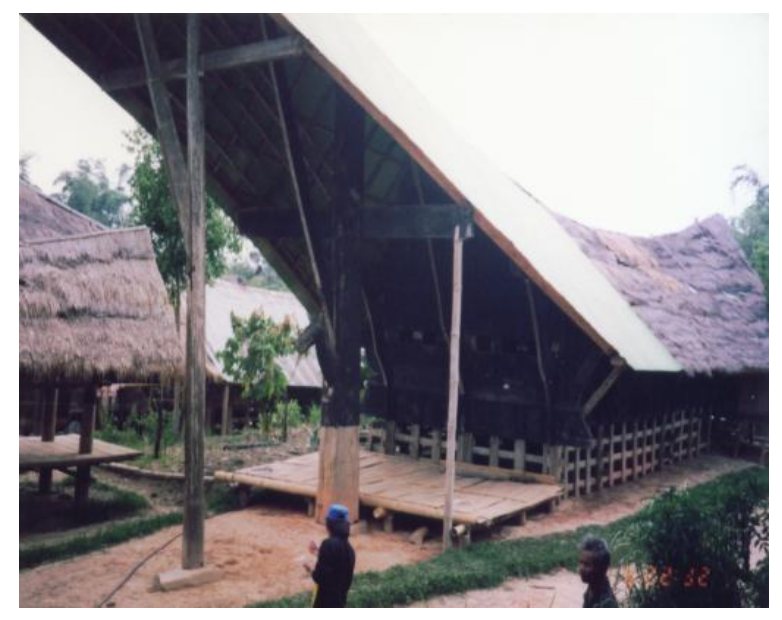

Gambar 4: Tipe banua bolong (Rumah berwarna hitam)

Sumber: Hasil Penelitian, 2013

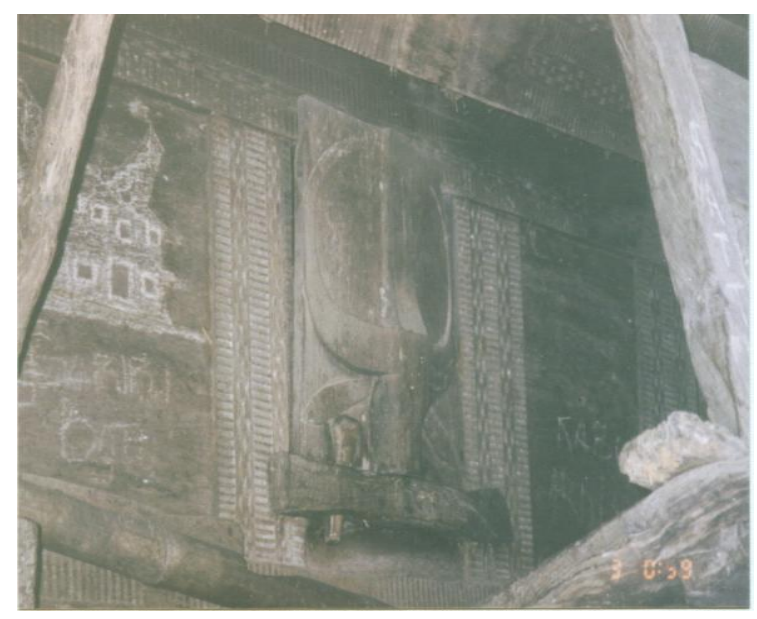

Gambar 5: Ukiran Pa'sussuk pada pinding dekat pintu Tipe banua sussuk Sumber: Hasil Penelitian, 2013

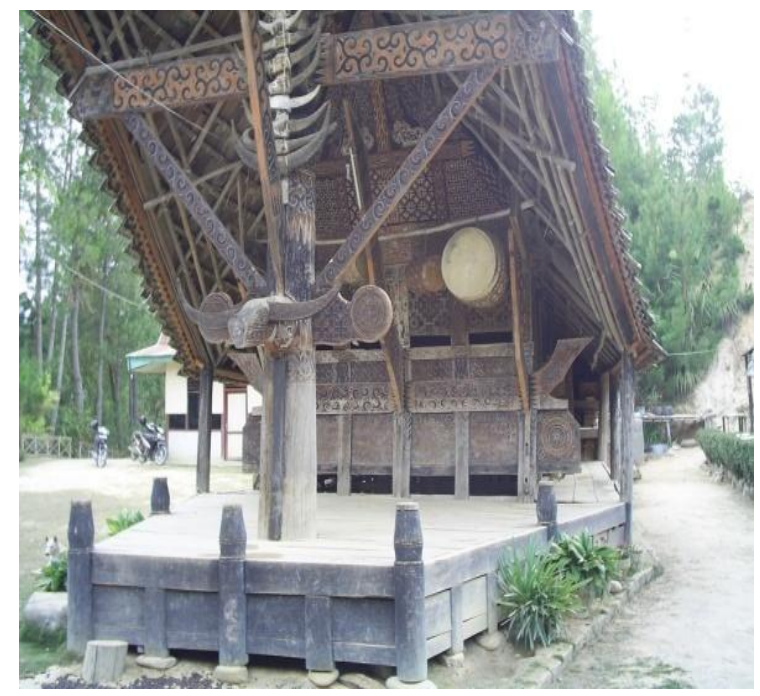

Gambar 6: Tipe banua sura' (rumah ukir). Sumber: Hasil Penelitian, 2013
Responden yang lain, $\mathrm{PH}$ Pualillin (2012) mengatakan bahwa: Rumah Mamasa terdiri atas empat tipe sesuai dengan tingkat starata social (kasta) Keempat tingkatan rumah tersebut adalah: 1) banua sura' (rumah ukir) biasanya dihuni oleh bangsawan tinggi (tana' bulawan) yang juga sekaligus memegang jabatan hadat dalam suatu komunitas (kampung); 2) banua bolong (rumah hitam), dihuni oleh kaum bangsawan biasa (tana' bassi) dan golongan tomakaka (orang kaya); 3) banua rapa' dihuni oleh golongan orang kebanyakan (tana' karurung); dan 4) banua longkarrin dihuni oleh golongan hamba (tana' koa-koa). Dimana golongan yang terakhir ini dihapuskan pada zaman Belanda. la berpendapat bahwa banua sura' yang dibuat tinggi (banua layuk), hanyalah karena yang empunya rumah disamping sebagai bangsawan tinggi dan mempunyai kedudukan hadat, dia juga kaya sehingga mampu membuat rumah seperti itu.

Pengklasifikasian atau tipologi rumah tradisional Mamasa ini, para responden memberikan jawaban yang hampir sama. Demikian juga jika dibandingkan dengan pendapat Mandadung (1999) dalam tulisannya tentang rumah tradisional Mamasa. Yang membedakan hanyalah dalam hal pengistilahan. Demikian juga setiap tingkatan klasifikasi itu, masih mempunyai tingkatan-tingkatan tersendiri, dilihat dari tata ruang, atau struktur dan konstruksinya serta ornamen yang dimiliki setiap rumah sebagai lambang identitas pemilik dalam hal kasta dan kedudukan sosial dalam masyarakat pada masa lampau.

Jika dihubungkan dengan pendapat Barliana (2004) tentang tipologi arsitektur, ditinjau dari site (tapak), nampaknya arsitektur tradsional Mamasa telah mempunyai pola site yang sudah baku, yaitu semua rumah menghadap ke Utara, atau ke hulu sungai, diatur dalam site tertentu dengan pola rumah sebagai bangunan induk, dan di depan atau di samping rumah lumbung (Alang) didirikan sebagai bahagian atau kelengkapan dari bangunan rumah tersebut. (Gambar 7).

Dari segi bentuk (form), dan pengorganisasian pengklasifikasian seperti yang dikemukakan para responden juga telah mempunyai bentuk yang baku, 
seperti yang diiperlihatkan pada gambar 1 sampai gambar 6 di atas.

Untuk menggambarkan site plan rumah tradisional Mamasa dapat dilihat pada sketsa gambar 7 .

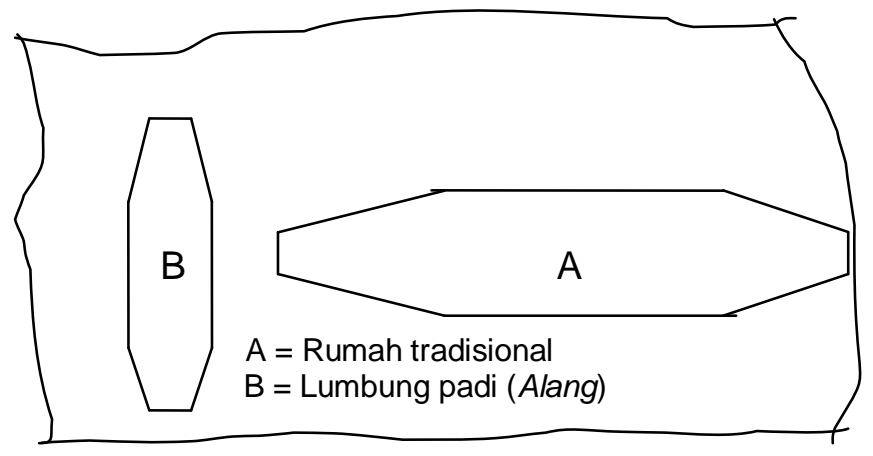

Gambar 7: Site Plan Rumah Tradsional Mamasa. (Dibuat untuk Penelitian)

Site plan seperti pada gambar 7 di atas, lebih lanjut dapat dilihat pada aplikasi di lapangan (Gambar 8 dan 9).

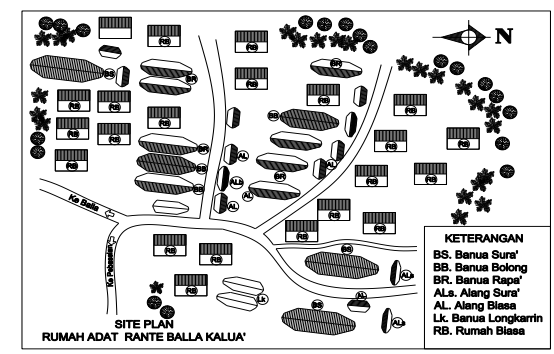

Gambar 8: Site Plan Perkampungan Tradisional Rante Balla Kalua' Sumber: Hasil Penelitian 2013

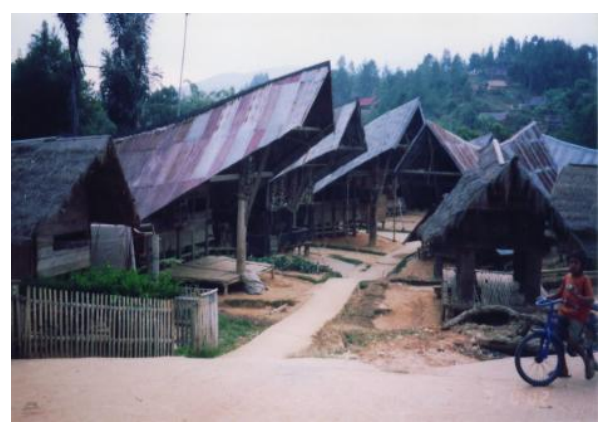

Gambar 9: Kampung Tradisonal Rante Balla Kalua

Sumber: Hasil Penelitian 2013

Gambar 9 memperlihatkan pola perkampungan tradisonal, yaitu rumah tradisonal berdiri sejajar dengan rumahrumah lainnya, dan di depannya berdiri lumbung padi (Alang). Tipologi site plan dan bentuk yang umum dan sudah baku untuk perkampungan tradisional Mamasa, sesuai dengan adat dan kebiasaan turuntemurun.

\section{Kesimpulan}

Berdasarkan pembahasan dari data berupa hasil wawancara dan foto-foto lapangan yang dibandingkan dengan literatur yang ada, dapat disimpulkan bahwa tipologi arsitektur tradisional Mamasa dilihat dari site plannya telah mempunyai pola yang tetap. Kemudiaan tipologi berdasarkan bentuk (form), dan pengorganisasian dapat diklasifikasikan sebagai berikut: 1) banua longkarrin (rumah sederhana), 2) banua rapa' (rumah yang berwarna alami), 3) banua disussuk (rumah yang diukir khusus), 4) banua bolong (rumah yang berwarna hitam), dan 5) banua sura' (rumah ukir).

\section{Glosarium}

Alang Lumbung padi

Ba'ba Pintu dan ruang tengah /ruang utama rumah.

Badong Ragam hias pada rumah sebagai symbol kebangsawanan

Banua Rumah

Banua Toban Rumah sederhana berbentuk box

Banua bolong Rumah bangsawan yang berwarna hitam

Banua Longkarrin Rumah tradisional yang pakai longkarrin/pondasi kayu

Banua rapa' Jenis rumah bangsawan

Banua sussukRumah ukir dengan ukiran pa'sussuk (ukiran vertikal dan horisontal)

Banua sura' Rumah ukir

Banualayuk Rumah ukir yang dibuat tinggi

Barung-barung Rumah sementara (darurat)

Bone Sejenis tumbuhan untuk zat pewarna hitam

Dua lantak Rumah dua ruangan

Lombon rumah

Lentong Tiang rumah

Lentong alla' Tiang tengah rumah

Longa Bagian atap yang menjulang tinggi di depan dan di belakang rumah.

Longkarrin Kayu memanjang/melintang yang mengikat ujung bawah tiang di dasar rumah berfungsi sebagai pondasi.

Penulak

Tiang utama rumah di depan 
dan di belakang untuk memikul beban konstruksi longa dan tempat memasang berbagai ornament yang bermakna simbolik.

Tado' Ruang bagian depan rumah

Tambing Ruang bagian tengah rumah untuk kaum wanita

Tana' Bulawan Bangsawan tinggi

Tana' Bassi Bangsawan menengah/ orang kebanyakan

Tana' koa-koa Hambah

\section{Daftar Pustaka}

Anonim,1998. Pengantar Arsitektur. Bahan penataran dosen arsitektur. Cisarua Bogor

Barliana, Syaom M. 2004. Tradisionalitas dan Modernitas Tipologi Arsitektur Masjid. Dimensi Teknik Arsitektur Vol.32 No.2 Hal. 110 - 118

Bonggalangi (Umur 70 tahun). Komunikasi Pribadi, Oktober 2013

Hellman, Louis. 1988. Architecture For Beginners. Amazon, Co.Uk

Mandadung, Arianus. 1999. Mamasa Dalam Lintasan Sejarah, Budaya, dan Pariwisata. Makassar

Mangunwijaya, Y.B. 1992. Wastu Citra. Gramedia, Jakarta

Mattulada. 1992. Penerapan Unsur Tradisional Kedalam Bangunan Baru. Seminar Nasional Kebudayaan dan Arsitektur, UGM, Yogyakarta

Pai'pinan (Umur 68 tahun). Komunikasi Pribadi, Juli 2013

PH Pualillin (Umur 70 tahun). Komunikasi Pribadi, Desember 2012

Poerwadarminta, W.J.R. 1984. Kamus Umum Bahasa Indonesia. PN. Balai Pustaka, Jakarta

Presiden Republik Indonesia. 2002. Undang-Undang No. 11 Tahun 2002 Tentang Pembentukan Kabupaten Mamasa dan Kota Palopo di Provinsi Sulewesi Selatan
Rebong (Umur 85 tahun). Komunikasi Pribadi, Maret 2012

Ruskin, J. 1992. Tradition and Architecture. University Press, Manchester

Siegel, Curt. 1962. Structure and Form in Modern Architecture. Vand Nostrad Reinholf, New York

Tandirandan (Umur 82 tahun). Komunikasi Pribadi, Oktober 2013 